\title{
Analysis on Value Added Tax and Income Tax Treatments of Two Special Businesses
}

\author{
Yuanyuan $\operatorname{Tian}^{1}$ \\ ${ }^{1}$ Zaozhuang University, Zaozhuang, Shandong Province, China
}

Keywords: Corporate Income Tax; Public Welfare Donation; Value Added Tax.

\begin{abstract}
The value-added tax and enterprise income tax are main burdens of enterprises in our country. In recent years, the state has constantly revised and improved regulations on these two taxes. Thus, financial personnel need to grasp latest policies to obtain accurate treatments of special businesses.
\end{abstract}

\section{Introduction}

In recent years, with the deepening of tax system reform in our country, laws and regulations related to enterprise income tax and value-added tax are being improved. In May 1, 2016, the value-added tax achieved full coverage of circulation, brought credit chain to the third industry; In February 24, 2017, The Twenty-Sixth Meeting Of The Twelfth Standing Committee of the National People's Congress passed the Amendment for Law on Corporate Income Tax. As the two most important kinds of tax in our country (according to relevant data released by the National Bureau of Statistics, in 2015, the corporate income tax revenue was 2,713,387 million yuan, accounting for $21.72 \%$ of the total tax revenue; the domestic value-added tax income was 3,110,947 million yuan, accounting for $24.9 \%$ of total tax revenue. If considers the implement of replacing business tax with value-added tax (VAT) in 2016, this data will be higher), these reforms have significant impacts on tax treatment of enterprises. According to the latest revision of laws on value-added tax and income tax, this paper makes analyses on the tax treatment of two special businesses.

\section{Public Welfare Donations Could be Deducted from Taxable Income}

The current The Law of the People's Republic of China on Enterprise Income Tax stipulates in article 9 that, in relation to charitable donation payments incurred by enterprises, the portion within $12 \%$ of the total annual profit may be deducted from taxable income. The portion exceed $12 \%$ of the total annual profit may be deducted for the next three consecutive years. The provision follows regulations on public welfare donation deduction in the Charity Law, aims to encourage enterprises to make more charitable donations, and implement the decision, "preferential tax policies should be stipulated in special tax laws and regulations", proposed in the Third Plenary Session of the 18th Central Committee of the CPC. The above amendments will be carried out and benefit for enterprises with public donations, since it can effectively reduce the tax burden of these enterprises. For example: in 2017, the total profit of a company is 5 billion yuan. The tax deduction limit for charitable donation is $50 \times 12 \%=0.6$ billion yuan. The actual donation is 800 million yuan. In 2017, 600 million yuan can be deducted from the taxable income; the remaining 200 million yuan can be carried forward to 2018. If the enterprise's profit in 2018 is 4 billion yuan, tax deduction limit for charitable donation will be $40 \times 12 \%=0.48$ billion yuan. If the actual donation is 250 million yuan, $0.25+0.2=0.45$ billion yuan can be deducted from the taxable income of 2018. The company can pay less income tax for $0.2 \times 25 \%=0.05$ billion yuan.

\section{Carry-over of Public Welfare Donations for Continuous Years}

The question is how to deal with public welfare donation carries forward for continuous years. Which data should be deducted first, the donation amount of this year or the remaining amount of 
previous years? For example, annual total profit and public welfare donations of a company from 2017-2010 are shown in the following table:

\begin{tabular}{|l|l|l|l|l|}
\hline item/year & 2017 & 2018 & 2019 & 2020 \\
\hline Total profit & 1000 & 2000 & 3000 & 4000 \\
\hline public welfare donations & 600 & 400 & 300 & 200 \\
\hline
\end{tabular}

There are two methods:

(1)The actual number of that year should be deducted first. If the data does not exceed the deductible amount, donation of previous years can be deducted. According to this method, the tax treatment should be:

2017: charitable donations deduction limit is $1000 \times 12 \%=1.2$ million yuan, the actual donation is 6 million yuan. The tax deduction of 2017 donation is 1.2 million yuan; the annual deduction after carry forward should be $6-1.2=4.8$ million yuan. The taxable income which should be added should be 4.8 million yuan.

2018: charitable donations deduction limit is $20 \times 12 \%=2.4$ million yuan, the actual donation is 4 million yuan. The tax deduction of 2018 is 2.4 million yuan; the tax deduction after carry forward should be $4.8+(4-2.4)=6.4$ million yuan. The taxable income which should be added should be 1.6 million yuan.

2019: charitable donations deduction limit is $30 \times 12 \%=3.6$ million yuan, the actual donation is 3 million yuan. The tax deduction of 2019 is $3+(3.6-3)=3.6$ million yuan; the tax deduction after carry forward should be 5.8 million yuan (2017 carry forward deduction is 4.8-0.6=4.2 million yuan, 2018 carry forward is 1.6 million yuan). The taxable income which should be deducted should be 0.6 million yuan.

2020: charitable donations deduction limit is $40 \times 12 \%=4.8$ million yuan, the actual donation is 2 million yuan. The tax deduction of 2020 is $2+(4.8-2)=4.8$ million yuan; the 1.4 remaining deduction of 2017 cannot be carried forward, while the 1.6 remaining deduction of 2018 can be carried forward. The taxable income which should be deducted should be 2.8 million yuan.

(2) The remaining number of previous years should be deducted first. If the data does not exceed the deductible amount, number of that year can be deducted. According to this method, the tax treatment should be:

2017: the same as the treatment method (1).

2018: charitable donations deduction limit is $20 \times 12 \%=2.4$ million yuan, the actual donation is 4 million yuan. The tax deduction carry forward from 2017 is 4.8 million yuan. The 2.4 million yuan is deducted from 2017 carryover; the taxable income which should be added should be 4-2.4 =1.6 million yuan. Both the carryover of 2017, namely 4.8-2.4=2.4 million and the deductible volume of 2018, namely 4 million can be deducted from taxable income of next year.

2019: charitable donations deduction limit is $30 \times 12 \%=3.6$ million yuan, the actual donation is 3 million yuan. The tax deduction carry forward from 2017, namely 4.8-2.4= 2.4 million yuan, and carryover from 2018, namely 3.6-2.4=1.2 million yuan are deducted first. The taxable income which should be deducted should be $2.4+1.2-3=0.6$ million yuan. The carryover of 2018 remains $4-1.2=2.8$ million yuan, the carryover of 2019 is 3 million yuan. Both of them can be deducted from taxable income of next year.

2020: charitable donations deduction limit is $40 \times 12 \%=4.8$ million yuan, the actual donation is 2 million yuan. The tax deduction carry forward from 2018, namely 2.8 million yuan, and carryover from 2019, namely 4.8-2.8=2 million yuan are deducted first. The taxable income which should be deducted should be $2+2.8-2=2.8$ million yuan. The carryover of 2019 remains $3-2=1$ million yuan, the carryover of 2020 is 2 million yuan. Both of them can be deducted from taxable income of next year.

By comparison we can find that, according to the first method, 1.4 million-yuan donation cannot be deducted as carryover after three years. According to the second method, this problem is solved. All charitable donations can be deducted. 
For tax avoidance, companies will agree with the second point of view to achieve the maximum amount of charitable donations for tax deduction. But the tax laws pay more attention to the protection of national tax benefits, and encourage enterprises to engage in charitable donations. But the limitation of deduction is three years; after three years, the donation cannot be carried forward to the next year. From this point of view, the second method seems more in line with the legislative intent. Since the amendment will take effect in April 2017, it is recommended that relevant departments should deal with the problem as soon as possible.

\section{Accounting Treatment of VAT Pay in Advance of Real Estate Enterprises}

In December 2106, the Ministry of Finance issued Provisions for Value-added Tax Accounting Treatment (Document of Finance and Accounting, [2016] No.22) which stipulates that, if the company pays VAT in advance, debit "tax payable - VAT pay in advance", credit "bank loans". At the end of term, the balance of "VAT pay in advance" should be transferred to "VAT payable", debit "tax payable - VAT payable", credit "tax payable - VAT pay in advance". By the time of tax obligation, "tax payable - VAT pay in advance" can be transferred to "tax payable - VAT payable". [1] The introduction of this provision means that, at least from the accounting perspective, the real estate enterprises cannot hedge "tax payable - VAT pay in advance" and "tax payable - VAT payable" at the end of the month, which will increase the actual value-added tax paid by real estate enterprises [2].

\section{Tax Treatment of VAT Pay in Advance of Real Estate Enterprises}

In the practice of real estate business, different projects often start at the same time. Different projects may take different taxation methods (simple method and general method), and have different commencements of tax obligation. Can the company use prepaid VAT input tax of one project to offset the output tax of other projects? At present, there are two views on this issue:

Method 1: In the case that a real estate company prepays the value-added tax for real estate projects developed by itself, the current tax payable of the value-added tax cannot be deducted until the commencement of tax obligation. For real estate projects which does not meet the commencement of tax obligation, the pre-paid value-added tax cannot be deducted between different projects. For example, a real estate enterprise has three projects A, B and C. A project is suitable for simple calculation method; B and C belong to general taxation projects. Three projects adopt sale methods of pre-payment. In January 2017, three projects received pre payment, and the prepaid value-added taxes are 1 million yuan, 2 million yuan and 3 million yuan respectively. In December 2017, A project needs to fulfill tax obligation, while $\mathrm{B}$ and $\mathrm{C}$ projects do not need to fulfill tax obligation at that time. The VAT payable of that month is 10 million yuan. After deduction, pre-paid value-added tax of A project, VAT should be 10-1=9 million yuan.

Reasons for above viewpoint are as follows. In accordance with Clause 14, Document No. 18 issued by State Administration of Taxation in 2016, general taxpayers who sell self-developed real estate projects should comply with Claus 45 of Pilot Implementation Measures for the Change from Business Tax to VAT (Fiscal Document [2016] No. 36) and calculate payable tax according to occurrence time of tax liability. During the current period, based on current sales volume and $11 \%$ tax rate, prepaid tax should be deducted, and tax declaration should be made to tax authorities. Deductible balance can be carried forward for set-off in the following periods. Corresponding policies are Interim Collection and Management Procedure on VAT Provided by Taxpayers Who Offer Real Estate Lease Service (Announcement of State Administration of Taxation, [2016] No.16 ), Interim VAT Collection and Management Measures for Taxpayers Who Provide Architectural Service across Counties, Cities or Districts (Announcement of State Administration of Taxation, [2016] No.17 ), Interim Collection and Management Procedure on VAT Provided by Taxpayers Who Transfer Real Estates (Announcement of State Administration of Taxation, [2016] No.14), which make the same stipulation on VAT prepayment for enterprises which lease real estates, provide construction labors or transfer their own real estates. VAT tax prepaid to local tax bureaus can be deducted from the current payable VAT, and deductible balance can be carried forward for off-set in 
following periods (Occurrence time of tax obligation is not regarded as the condition for deduction of prepaid VAT)

By comparing these documents, it can be found that State Administration of Taxation makes totally different provisions between real estate enterprises' VAT pay in advance for self-developed real estates and the businesses of leasehold estates, construction services and transferring of self-owned real estates. The reason lies in that, taxpayers' transferring of real estates, providing construction services and rental services create VAT tax obligations in the same month of paying VAT in advances. Naturally, the prepaid taxes can be deducted from payable tax in the tax declaration of next month. However, for real estate enterprises' self-developed projects, the duration from prepaying VAT to tax liability is relatively longer. In order to ensure the interests of the state, payable tax must be deducted until the time of tax liability. From the denotative meaning of these documents, it can be understood that State Administration of Taxation agree the view that prepaid VAT for different projects cannot be deducted from each other. The above-mentioned provisions issued by the Ministry of Finance are also consistent with those regulations issued by State Administration of Taxation.

Method 2: In the case that a real estate company prepays the value-added tax for real estate projects developed by itself, the current tax payable of the value-added tax can be deducted if one project need to fulfill tax obligation. For example, a real estate enterprise has three projects A, B and C. A project is suitable for simple calculation method; B and C belong to general taxation projects. Three projects adopt sale methods of pre-payment. In January 2017, three projects received pre payment, and the prepaid value-added taxes were 1 million yuan, 2 million yuan and 3 million yuan respectively. In December 2017, A project needs to fulfill tax obligation, while B and C projects do not to fulfill tax obligation at that time. The VAT payable of that month is 10 million yuan. After deduction, pre-paid value-added tax of A project, VAT should be 10-1-2-3=4 million yuan.

People who holds this view believes that, if the government does not allow the deduction of VAT between different projects of the same real estate company, and insists that VAT should be calculated separately, then input value-added tax should also be calculated separately, which break the rules of input VAT accounting. In fact, it turns value-added tax into land value-added tax, which is not only theoretically illogical, but also difficult to grasp in practice. The author also agrees with this view. The aim of VAT in advance is to ensure the national tax benefits, while this goal has been achieved through value-added tax paid in advance. Thus, VAT pay in advance should be allowed to offset VAT of other projects.

Both two views are reasonable. Different enterprises and different provinces also have different understandings on that document. The Ministry of Finance and the State Administration of Taxation need to clarify this issue as soon as possible.

\section{References}

[1] Ministry of Finance, Provisions for Value-added Tax Accounting Treatment (Document of Finance and Accounting, [2016] No.22)

[2] Z.M. Zou, Treatment on value-added tax and related business in real estate enterprises after the Change from Business Tax to Value-Added Tax, J. Finance and Accounting. 21 (2016). 